\title{
Tutkija turneella - sosiaalipedagogisia merkintöjä teatterikiertueelta
}

\author{
Sanna Ryynänen
}

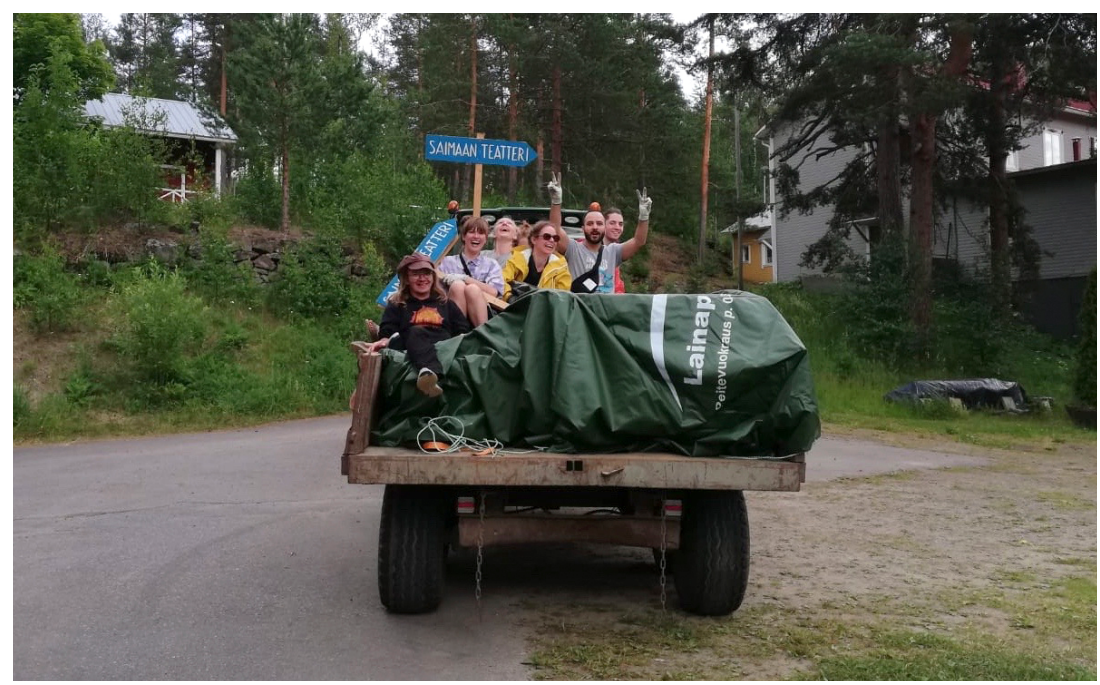

\section{TIIVISTELMÄ}

- Saimaan Teatteri on vuonna 2014 perustettu nuorten ammattinäyttelijöiden kiertueteatteri, joka kiertää kesäisin laivalla Saimaan alueen kyliä noin kuukauden ajan. Esiintymispaikat ovat vanhoja seuran- ja työväentaloja. Kuvaan tekstissäni omien kokemusteni kautta ja sosiaalipedagogisten näkökulmien virittämänä Saimaan Teatterin vuoden 2019 kesäkiertuetta, jolle osallistuin tutkijana. Hahmottelen Saimaan Teatterin kiertuetoimintaa yhteisöllisenä tilana, pohdin teatterin toimintatapaa esimerkkinä jalkautuvasta ja kulttuurisen demokratisaation periaatetta edustavasta teatterityöstä sekä kuvaan esimerkinomaisesti Saimaan Teatteria kohtaamisten mahdollistajana. Tekstin ja sitä kehystävän laajemman tutkimushankkeen yhtenä tavoitteena on hahmotella jotakin sellaista, mitä kutsun teatterin tai laveammin taiteiden sosiaalipedagogiikaksi.

Avainsanat: teatteri, Saimaan Teatteri, sosiaalipedagogiikka, kulttuurinen demokratisaatio 


\section{ABSTRACT}

\section{TOURING RESEARCHER -}

\section{A THEATRE TOUR THROUGH SOCIO-PEDAGOGICAL LENSES}

- Saimaa Theatre is a touring theatre group of young professional actors in Finland, established in 2014. In the summertime, the theatre group travels around the small villages in the lake Saimaa region for a month by boat. The venues are old community houses. In my text, I describe, through my own experiences and socio-pedagogical perspectives, the Saimaa Theatre summer tour of 2019, that I participated as a researcher. I outline the touring life of the Saimaa Theatre as a communal space, reflect on the way the theatre operates as an example of the principle of cultural democratisation, and portray the Saimaa Theatre as a space that enables encounters. One of the aims of the text and of the research project framing it is to outline what I call the social pedagogy of the theatre and the arts.

Key words: theatre, Saimaa Theatre, social pedagogy, democratisation of culture

\section{Johdanto}

G aimaan Teatteri on vuonna 2014 perustettu nuorten ammattinäyttelijöiden kiertueteatteri, joka kiertää kesäisin Saimaan alueen kyliä noin kuukauden ajan esiintyen vanhoissa seuran- ja työväentaloissa. Teatterin toiminta-ajatuksena on viedä kunnianhimoista, uudistavaa esitystaidetta paikkoihin, joissa sellaista ei yleensä ole tarjolla. Monella ryhmän jäsenellä on jokin henkilökohtainen side Saimaan alueeseen ja siten syy tehdä teatteria ja elvyttää kulttuuriperinnettä nimenomaan Saimaan seudulla. Omaleimaista kiertuetoiminnasta tekee se, että teatteriseurueen kulkuvälineenä ja majapaikkana on kiertueen ajan mikkeliläisen meripartiolippukunta Ekin Partio ry:n Lola3-alus. Toinen vastaava kiertueteatteriryhmä Suomessa on Turun saaristossa jo vuodesta 1969 kesäisin seilannut Skärgårdsteatern, josta Saimaan Teatterin perustaja, näyttelijä Wilhelm Grotenfelt sai innoituksen tehdä jotakin vastaavaa omalla kotiseudullaan.

Yhteiskuntatieteellisesti virittynyt kiinnostus teatteriin ja juuret Saimaan seudulla ovat kuljettaneet myös minut, sosiaalipedagogiikkaan erikoistuneen yhteiskuntatieteilijän ja tutkijan, mukaan Saimaan Teatterin toimintaan. Osallistuin tutkijana kesän 2019 produktion taustatyöhön, seurasin läheltä Saimaan Demokraattinen Tasavalta -näytelmän (ohjaus Piia Peltola) valmistumista sekä kiersin teatteriseurueen mukana koko neliviikkoisen kiertueen ajan kesä-heinäkuussa 2019. Syksystä 2019 lähtien 
olen ollut Saimaan Teatterin tutkijajäsen. Teatterin kolmivuotissuunnitelmaan 2020-2022 on kirjattu yhdeksi painopistealueeksi taiteen ja tutkimuksen vuoropuhelun vahvistaminen ${ }^{1}$. Etsimme yhdessä kokeillen, mitä kaikkea esittävän taiteen ammattilaisten ja yhteiskuntatieteilijä-tutkijan yhteistyö voi olla sekä millaista uutta ajattelua ja toimintaa se voi tuottaa tieteen ja taiteen kentille.

Tässä katsaustekstissä kuvaan Saimaan Teatterin vuoden 2019 kesäkiertuetta omien kokemusteni kautta, sosiaalipedagogisten näkökulmien virittämänä. Kursivoidut katkelmat ovat kiertuepäiväkirjastani. Tekstin ja sitä kehystävän laajemman tutkimushankkeen ${ }^{2}$ yhtenä tavoitteena on hahmotella jotakin sellaista, mitä voisi kutsua teatterin tai laveammin taiteiden sosiaalipedagogiikaksi. Ymmärrän sen teatteriin ja esittäviin taiteisiin kohdistuvaksi ajatteluksi ja toiminnaksi, joka on kiinnostunut teatterista ihmisenä olemisen ja ihmisenä kasvamisen perustavanlaatuisiin kysymyksiin kutoutuvana toimintana, yhteentulemisen, kohtaamisen ja dialogin tilana sekä yhteiskunnallisena tai poliittisena tekona, joka eri tavoin muokkaa ja rakentaa ihmisten yhteisö- ja yhteiskuntasuhdetta (sosiaalipedagogiikan kolmitasoisesta toimintaorientaatiosta ks. Nivala \& Ryynänen 2019, 28). Katsausteksti on ikään kuin kevyttä lämmittelyä ennen kuin tartun keräämäni laajan tutkimusaineiston varsinaiseen analyysiin.

\section{Kiertue-elämää}

Lauantai 6.7.2019 - Herään laveriltani Lola3-laivalla työryhmän ensimmäisenä, jo ennen kahdeksaa. Päiväni alkaa aamu-uinnilla päivä päivältä hyytävämmäksi muuttuvassa Saimaassa, jonka kylmään syliin kapuan laivan takaosan uimatikkaita pitkin. Laivan saunan eteen viritetyt pyykkinarut ovat eilisillan saunomisen jäljiltä täynnä seurueemme pyyhkeitä sekä kankaisia istuma-alusia, joita olemme alkaneet kutsua Savonlinnan torilla oppimallamme nimellä pyllykkä.

Työryhmässä meitä on yhteensä seitsemän: neljä näyttelijää, tuottaja, kiertueteknikko sekä minä, yhteiskuntatieteilijä/sosiaalipedagogi/tutkija. Lisäksi elämänpiiriimme kuuluu läheisesti laivan noin kolmen päivän välein vaihtuva henkilökunta eli kapteeni ja yksi tai kaksi apuhenkilöä sekä satunnaiset vieraat eli työryhmän jäsenten kumppanit ja kaverit. Meidän

1 Koneen Säätiön kolmivuotinen toiminta-avustus: "Saimaan Teatterin taiteellisen toiminnan kehittäminen ja yhteiskuntatutkimuksen integroiminen työskentelyyn", 2020-2022.

2 Koneen Säätiön rahoittama kolmivuotinen tutkimushanke "Lähiöbaareissa ja seurantaloilla. Tutkimus teatterista ja esitystaiteesta yhteiskunnallisina tekoina", 2020-2022. 
käytössämme on laivan yhteisistä tiloista oven erottama nukkuma-alue, jossa on kolme erikokoista hyttiä sekä kahdella laverilla varustettu avotila. Minä, ryhmän parhaat unenlahjat omaavana, nukun avotilan alapedissä. Parisängyn levyisen nukkuma-alueeni käytävänpuoleista reunaa hallitsevat matkalaukkuni sekä kaaokseksi ryöpsähtänyt kasa vaatteita, kirjoja, peseytymistarvikkeita ja muistiinpanovälineitä. Kasan alta pilkottavat tietokone ja nauhuri sekä solmuisa vyyhti latureita johtoineen. Viimeksi eilen näyttelijät kiusoittelivat minua siitä, että olen meistä kaikkein sotkuisin, ja kuvasivat kaaosmaisesta laveristani videoita Saimaan Teatterin Instagramiin. Minä puolestani lähetin heille yhteisen Whatsapp-ryhmämme kautta linkkejä tutkimuksiin, joissa sotkuisten ihmisten on todettu olevan erityisen älykkäitä ja luovia.

Pukeuduttuani avaan hetkeksi tietokoneen. Yritän hyödyntää hiljaisen aamuhetken keskittyneempään työntekoon - rauhallisia hetkiä kiertue-elämässä kun ei juurikaan ole. Kirjaan kiertuepäiväkirjatiedostooni muistiin eilisen tapahtumia ja esitystunnelmia sekä kirjoitan puhtaaksi esityksen jälkeen saadut palautelomakkeet. Muutaman jatkohaastatteluun lupautuneen katsojan yhteystiedot siirrän syrjään, yritän soittaa heille iltapäivällä roudauksen jälkeen haastatteluajoista sopiakseni.

Olin tiennyt Saimaan Teatterin olemassaolosta jo usean vuoden ajan ennen kuin päädyin itse mukaan sen toimintaan. Kun kesän 2019 produktio sai rahoituksen ja myös minun mukanaoloni varmistui, kuvittelin mielessäni, millaista kiertueteatterin tekeminen on ja millaista on olla nimenomaan laivakiertueella. Mieleen tulivat niin tosi-tv-ohjelmat vuoden 1981 Ylen Aikapommista (Yle 2006) nykypäivän Big Brotheriin kuin monet klassiset sosiaalipsykologian koeasetelmat, joissa joukko ihmisiä suljettiin samaan tilaan vuorovaikutuksen mekanismien selvittämiseksi. Kun kerroin kavereilleni tulevasta kesästäni, huomasin usein vertaavani tutkijana teatterikiertueelle lähtemistä ihmiskokeeseen. Mielessä pyöri myös sukuhistoriani. Isoisäni teki työuransa Saimaalla puutavaraa kuljettavilla höyryhinaajilla, isoäitini työskenteli monena kesänä samoissa laivoissa keittäjänä ja isäni kesätöissä kansipoikana. Laivakiertueella pääsisin jatkamaan sukuni perinnettä laivatöistä kolmannessa sukupolvessa. Se tuntui merkitykselliseltä, vaikka huomasin miettiväni, olisiko ruumiillista työtä arvostanut isoisäni pitänyt etnografisen tutkijan työtä teatterikiertueella "oikeana työnä".

Jotkin ennakko-oletukseni laivalla toteutettavasta teatterikiertueesta osoittautuivat aika osuviksi. Esimerkiksi ihmiskoe-vertaus ei tuntunut 
lainkaan kaukaa haetulta. Pienehkö laiva on sosiaalisena tilana erityinen. Se tuottaa senkaltaisen fyysisen ja emotionaalisen läheisyyden tilan ja tilanteen, jota muunlainen matkustus- ja majoitusjärjestely ei mahdollistaisi eikä myöskään edellyttäisi. Heräsimme, laitoimme ruokaa, söimme, roudasimme, rakensimme, nauroimme, saunoimme, uimme, osin myös nukuimme yhdessä. Pesimme hampaita toistemme edessä, kuljimme yövaatteissa. Elimme neljä viikkoa lähes taukoamatta yhdessä, tiiviisti ja intiimisti.

Tiistai 9.7.2019 - Kävelemme Boodin kanssa kohti Puumalan sataman pesutupaa. Olemme viimeksi pesseet vaatteitamme Juvalla pari viikkoa sitten, eli likapyykkejä on kertynyt monta kassillista. Kaadamme kaiken pesutuvan pöydälle, vedämme muovipussit käsiin ja alamme lajitella. Näyttelijöiden esiintymisvaatteet, kaksi kasaa mustaa pyykkiä, yksi kasa kirjavaa, yksi vaaleaa. Nostelemme seurueemme alushousupyykkiä eri kasoihin. Naurattaa: tämä on jo aika intiimiä yhteiseloa.

Jatkuva yhdessä oleminen ja yhdessä tekeminen tiivistivät laivalla seilaavan työryhmämme väliaikaiseksi mutta kiinteäksi yhteisöksi. Minulla ei ollut ryhmässä omaa selkeää roolia kuten muilla eli näyttelijöillä, tuottajalla ja teknikolla, mutta siitä huolimatta huomasin kiertueen edetessä mieltäväni itseni yhä enemmän osaksi työryhmää sen sijaan, että olisin ajatellut olevani tutkijana ulkopuolinen havainnoitsija. Etenkin kiertueen loppupuolella mieleeni tuli usein joitakin vuosia sitten lukemani juttu sosiologi Jussi Perälästä, joka vietti tutkimustensa vuoksi kymmenen vuotta Helsingin huumepiireissä. Hän on kuvannut, kuinka tuona aikana huumediilereistä tuli ystäviä, jotka syrjäyttivät vanhat ystävyyssuhteet ja kuinka arkeen oli vaikeaa palata. (HS 13.6.2013.) Yhtäkkiä ymmärsin Perälää paljon paremmin kuin aiemmin. Itse olin "kentällä" yhteensä vain pari kuukautta, josta intensiivistä kiertueaikaa oli kuukausi, mutta jo sinä aikana työryhmästä ja Lola3-laivasta muodostui elämääni omalaatuinen kupla, jonka ulkopuolinen maailma haalentui johonkin kauas ja yhteydenpito muihin ihmisiin kutistui vähäiseksi.

Lähes taukoamaton yhdessäolo loi tilan syville ja suorille kohtaamisille ja kohdatuksi tulemisille sekä rakensi kiinnostavan yhteisöllisen vuorovaikutuksen tilan. Ne eivät kuitenkaan syntyneet itsestään vaan edellyttivät yhdessäoloon liittyviä monenlaisia neuvotteluja. Yhteiselämän erityinen, intiimi tila kutsui reflektoimaan sekä itseä ja omia toimintatapoja että dialogin ja demokraattisen työtavan mahdollisuuksia ja sudenkuoppia 
aivan uusista näkökulmista. Tiiviissä yhteiselämässä ei konflikteiltakaan tietenkään vältytty.

Keskiviikko 3.7.2019 - Kannamme tuottaja-Elinan kanssa katsomon muodostaneita oransseja muovituoleja Oravin nuorisoseurantalon pihalla odottavaan pakettiautoon. Traktori perälavoineen on peruutettu oven eteen vastaanottamaan lavasteet ja näyttämötekniikan. Kun saamme omat tavaramme kannettua traktorin lavalle, raahaamme vielä aamulla talon seinustalle viemämme huonekaluröykkiön takaisin sisään. Monessa esiintymispaikassa tila täytyy ensin tyhjentää siellä majailevasta tavarasta ennen kuin me ja lavasteemme mahdumme sisään. Jotkut vanhat kokopuiset pöydät ovat niin painavia, että saamme ne hädin tuskin pareittain kannettua. Vielä viimeinen silmäys saliin, ja olemme valmiita itsekin hyppäämään traktorin lavalle. Vilkaisen kännykän kelloa: vähän vaille yksitoista. Siitä, kun aamulla aloitimme roudauspuuhat, on nyt jotakuinkin 13 tuntia. Traktorin kääntyessä pois seurantalon pihasta, Pietu kaivaa harppunsa esiin sitä suojaavasta mustasta jätesäkistä ja alkaa näppäillä näytelmässä Klausin (Jonnakaisa Risto) esittämän On suuri sun rantas autius -laulun säveliä. Jonnakaisa alkaa laulaa, ja pian lauluun yhtyvät kaikki seurueen laulutaitoiset. Niin kaunista, että pakahduttaa. Hetkessä tiivistyy jotain vanhojen suomalaisten elokuvien nostalgista maaseutusuomalaisuutta tavalla, joka tuntuu juuri tässä hetkessä raikkaalta ja lempeältä. Kaartaessamme satamaan laivan taakse laskeva aurinko värjää taivaan oranssinpunaiseksi.

Edessä on vielä päivän viimeinen roudaus: tavarat traktorin lavalta laivan kannelle. Viereiselle laituripaikalle on kiinnittynyt kaunis vanha höyrylaiva, jonka kannella joukko nuoria miehiä viettää iltaa. Jonnakaisa käy pyytämässä miehet meille kantoavuksi. Lasken mielessäni, että tähän mennessä olemme tänään kantaneet jotakin johonkin jo yhdeksän kertaa: 1. tavarat laivasta laiturille, 2. laiturilta traktoriin, 3. traktorista seurantalolle, 4. seurantalon tavarat verannalle ja 5. verannalta talon seinustalle, 6. katsomon tuolit sisään, 7. katsomon tuolit ulos, 8. meidän tavarat traktoriin ja 9. seurantalon tavarat talon seinustalta sisään. Kuin arvaten ajatukseni päivän kymmenennen kantourakan äärellä, traktorikyydin tarjonnut paikallinen isäntä toteaa näyttelijöille: "Onhan tuossa omalaatuinen homma teilläkin - että taitaa siihen joku kipinä olla". 


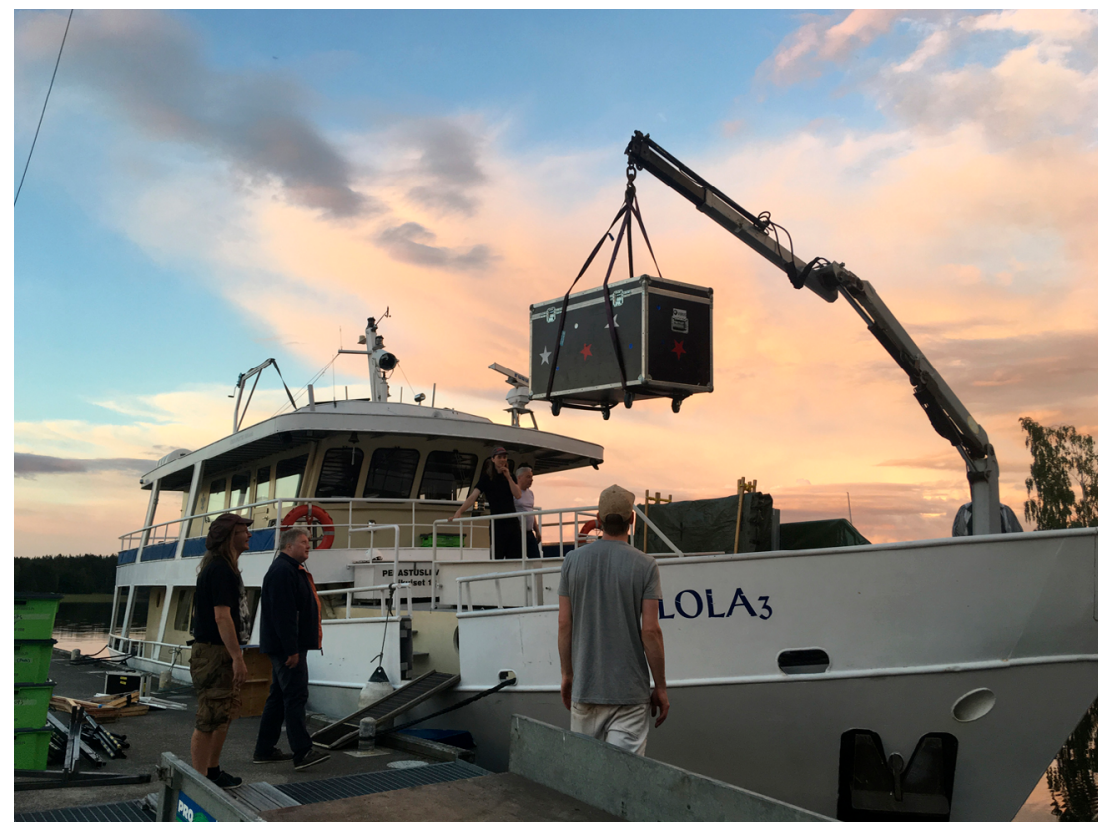

Kuva: Sanna Ryynänen

Moni ennakko-oletukseni kiertue-elämästä osoittautui myös vääräksi. Luulen, että jopa isoisäni olisi pitänyt kiertueteatteria oikeana työnä, jos olisi nähnyt kiertueeseen sisältyvän ruumiillisen työn määrän. Yhden esityksen pystyttäminen ja purkaminen vaativat valtavasti työtä. Kuorman purkaminen laivasta, kuljettaminen määränpäähän, kantaminen esityspaikkaan, näyttämön ja tekniikan pystyttäminen, aina uusien sähköasioiden miettiminen, sound-check, esitys, näyttämön ja tekniikan purkaminen, pakkaaminen, kantaminen, kuljettaminen ja lastaaminen takaisin laivaan veivät esityspäivinä vähintään kymmenen tuntia.

Maanantai 1.7.2019 - Huomioni on jo kiinnittänyt esitysten vaatiman valtavan työmäärän lisäksi se, että työryhmä ei tee mitään joten kuten tai helpoimman kautta vaan asenteella, jossa yksinkertaisten ratkaisujen sijaan pyritään koko ajan, voimia säästämättä, parhaaseen. Ammattiteatteriesityksen tuominen hiljentyviin kyliin ja rapistuville seurantaloille on merkittävä teko jo sinällään, ja Saimaan Teatterin ensemble tekee sen sekä paneutuen että rakastaen niin työtään kuin Saimaan seutua. (Facebook-päivitys) 
Minä tein teatteriammattilaisten mukana sen minkä osasin: kannoin tavaroita, autoin näyttämön pystytyksessä, järjestelin katsomoita, myin lippuja, laitoin ruokaa - ja yritin kirjata muistiin sen, minkä ehdin. Kannoin kehossani roudauksen synnyttämiä mustelmia kuten muutkin työryhmän jäsenet, ja väsymys kertyi minuunkin kiertueviikkojen edetessä. Minulle tutkijana kokemus olisi muodostunut hyvin erilaiseksi, jos olisin vain pistäytynyt joillakin kiertuepaikkakunnilla, ollut mukana vain osan kiertueesta tai jostain syystä kyvytön osallistumaan yhteisiin töihin, kuten roudaukseen ja ruoanlaittoon. Saimaan Demokraattinen Tasavalta -näytelmän näin valmiina 19 kertaa, mikä kuljetti minut huomaamaan teatterintekemisestä ja -kokemisesta aivan uudenlaisia asioita - sellaisia, joita en olisi nähnyt tai havainnut vain muutaman esityskerran perusteella.

Tiistai 9.7.2019 - Vaikka olen nähnyt näytelmän jo yli kymmenen kertaa, huomaan, että minulle käy samoin kuin kaikissa aiemmissakin esityksissä tähän mennessä: näytelmän alussa kirjaan muistiin huomioitani lipunmyynnin yhteydessä käydyistä keskusteluista, salissa vallitsevasta tunnelmasta sekä näyttelijöiden ja yleisön välille rakentuvasta tilasta. Jossain vaiheessa näytelmä alkaa kuitenkin imeä huomiotani puoleensa niin, että vihko valahtaa syliini ja huomaan olevani taas yksi katsoja muiden joukossa. Mielessä vilahtaa ajatus siitä, miten erityislaatuisella tavalla hienoa elävä näyttämötaide on. Esitys ei ole koskaan täysin sama. Se ei rakennu näyttämöllä vaan jossakin esiintyjien ja yleisön välille muodostuvassa tilassa, jonka energia ja lataus ovat aina erilaiset. Kyse on ikään kuin kehästä, joka lähtee pyörimään joko sellaiseen suuntaan, jossa näyttelijöiden ja yleisön välisyys alkaa ruokkia toisiaan yhä merkityksellisemmän yhteisen tilan rakentumiseen, tai sellaiseen, jossa aletaan luisua jollakin tavoin eri raiteille, merkityksiä rakentavan yhteisyyden liukuessa koko ajan pikemminkin kauemmaksi. Etukäteen on täysin mahdotonta ennustaa, kumman kierteen esitys kulloinkin ottaa. Se on mysteeri, jota palaamme yhä uudelleen pohtimaan työryhmän kanssa erityisesti saunan lauteilla esityksen jälkeen.

\section{Paikkoja}

Saimaan Teatteri on syntynyt tarpeesta viedä kiertueteatterina ammattimaista esitystaidetta paikkoihin, joissa sitä ei juurikaan tai lainkaan (enää) ole. Vuoden 2019 kesäkiertue alkoi Juvalta 24.6.2019 ja päättyi neljä viikkoa myöhemmin Ruokolahden Virmutjoelle. Juvalta käsin kävimme en- 
simmäisen kiertueviikon aikana autokyydillä Heinävedellä, Sorsakoskella, Kuopion Rytkyssä ja Sulkavalla. Sulkavan työväentalon esityksen jälkeen muutimme Lola3-alukseen. Saimaan aalloilla seilaten esitys vieraili Oravissa, Kokonsaaressa, Moinsalmella, Kiviapajassa, Puumalassa, Anttolassa, Himalansaaressa, Taipalsaarella ja Joutsenossa ennen viimeistä etappiamme, Virmutjokea.

Perjantai 5.7.2019 - Saarikansan työväentalo Kokonsaaressa: perinteinen punainen hirsitalo mäellä 60-luvun asussaan ilman juoksevaa vettä tai muita mukavuuksia - ja niin lähellä laituria, että kannamme tavarat ketjussa suoraan laivalta lavalle. Nurkkien pölykasat vaikuttavat useiden vuosien aikana kertyneiltä, sivuhuoneista löytyvät tavarat ovat 50-60-luvuilta. Paikallisen työväenyhdistyksen puuhamies kertoo, että huippuaikoinaan Tanssitalon tansseihin saatettiin myydä 700 lippua, ja vappujuhliin kerääntyi jopa 1500 juhlijaa. Nyt sen yllä leijuu menneen maailman henki. Se kuljettaa minut omien seurantalomuistojeni ääreen. Niistä ensimmäiset ovat Suomenniemen nuorisoseurantalon iltamista, joihin isovanhempani minut alle kouluikäisenä veivät. Mieleen on painunut erityisesti ohjelman jälkeiset tanssit ja perunajauhoilla liukastettu puulattia, jolla tanssin mummoni kanssa valssia ja humppaa. Tuntuu kuitenkin siltä, että vasta tänä kesänä minulle on muodostumassa seurantalosuhde.

Saimaan Demokraattinen Tasavalta -näytelmä vieraili kesällä 2019 yhteensä viidellätoista seuran- ja työväentalolla Saimaan alueella. Vanhimmat taloista ovat 1900-luvun alkuvuosikymmenien hirsiseinäisiä kaunottaria, tyypillisesti talkoilla rakennettuja. Niiden tarinoissa tiivistyvät kyläyhteisöjen yhteisöllinen elämä ja toiminta, samoin kuin Suomen historian eri vaiheet. Kuulimme kertomuksia yhteisöllisistä ponnistuksista sodan jälkeen, kun kodittomaksi jääneitä ihmisiä majoitettiin seurantalojen tupiin, sekä villejä tarinoita ihmisiä pursunneista tansseista 1950-luvulla. Yhdessä paikassa talon kahvion tiskiä reunustavat työväenyhdistyksen viirit, toisen yläpuolella roikkuu kyltti "Lotta-kahvio". Näyttämöiltä ja takahuoneista löytyi aarteita vanhoista gramofoneista 1920-luvun köydenvetokunniakirjoihin. Näyttämöt vanhoine lavastekankaineen kutkuttivat mielikuvitusta: Saimaan Teatteri asettuu vierailuillaan pitkän yhteisöllisen kulttuuritoiminnan jatkumoon. Seuran- ja työväentaloja voisi myös ajatella jonkinlaisina suomalaisen sosiaalipedagogiikan varhaishistorian monumentteina. 
Keskiviikko 3.7.2019 - Seurantalon lavalta löytynyt laho kohta hulvauttaa mieleen haikeuden, jota moni muukin esiintymispaikoistamme on jo kirvoittanut - ja jota myöhemmin päivällä lavalle ilmestyvä vanerilevy ei hälvennä. Moni kiertueemme kauniista ja perinteikkäistä, monivaiheista historiaa kantavista seuran-, nuorisoseuran- ja työväentaloista on jo rapistunut surullisen huonoon kuntoon, eikä taloja hallinnoivilla kyläyhdistyksillä tai nuorisoseuroilla ole välttämättä rahaa edes ylläpitokorjauksiin, puhumattakaan suuremmista kunnostuksista. Oravissa ilmestyvän Kanavan Varrelta -lehden kesän 2019 numerossa siteerataan kyläyhdistyksen vuoden 2018 toimintakertomusta: "Nuorisoseuran talo oli tapetilla vuoden aikana, kun talon kustannukset vievät yhdistyksen kaikki toimintarahat. Talon myyntiäkin harkittiin vakavasti. Samoin nuorisoseuran lopettamista mietittiin. Ylimääräinen kokous järjestettiin syksyllä aiheesta, mutta aihe ei ollut osallistujien määrästä päätellen kiinnostava." (Kanavan Varrelta, kesä 2019, 6). Haikeuden lomaan kiilaa ajatus siitä, miten tärkeää tapahtumien tuominen juuri näihin vanhoihin, pitkälti jo käyttämättöminä seisoviin rakennuksiin on: asetumme osaksi vuosisataista jatkumoa. Tavaroiden kantamiseenkin tulee taas uudenlaista mielekkyyttä: tämä on pieni mutta tärkeä teko. Traktorikuskimme toteaa, että Saimaan Teatterin vierailu paikkakunnalla on aina yksi kesän kohokohdista.

Saimaan Teatteri paitsi osallistuu kiertueellaan seuran- ja työväentalojen edustaman paikallishistorian ja -kulttuurin ylläpitämiseen myös muistuttaa talojen olemassaolosta ja lisää niiden tunnettavuutta alueen vakituisten ja kesäasukkaiden parissa. Illasta toiseen osa yleisöstä kertoo astuneensa paikkakunnan seuran- tai työväentalolle ensimmäistä kertaa. Osalle yleisöstä talot edustavat puolestaan pitkää sukuhistoriaa: isovanhemmat ovat olleet niitä rakentamassa ja vanhempien - sekä ehkä myös omat - häät on tanssittu seurantalon perunajauhotetulla lattialla.

Seurantalovierailut herättivät kuitenkin monesti haikeutta ja surua. Moni kaunis talo on todella huonossa kunnossa ja ilmeisen vähäisellä käytöllä, ja monella paikkakunnalla taloista huolehtivat kyläyhdistysten ja maamiesseurojen vastuuhenkilöt ikääntyvät. Nuoria talojen elinvoimaisuuden varmistava ja niiden kuntoa ylläpitävä talkootoiminta ei kuulemma useinkaan kiinnosta. Seurantaloissa tiivistyy valtava määrä paikallishistoriaa ja -yhteisöllisyyttä, joka tuntuu liukuvan monessa paikassa koko ajan kauemmas, nostalgiaksi. Mitä etenkin huonokuntoisimmille 
taloille ja niiden kantamalle paikallishistorialle tapahtuu tulevina vuosikymmeninä, tuo kysymys hiipi mieleen kerta toisensa jälkeen. Voisiko Saimaan Teatteri ottaa myös jotenkin vahvemmin kantaa työväen- ja seurantalorakennusten ja -perinteen säilymisen puolesta?

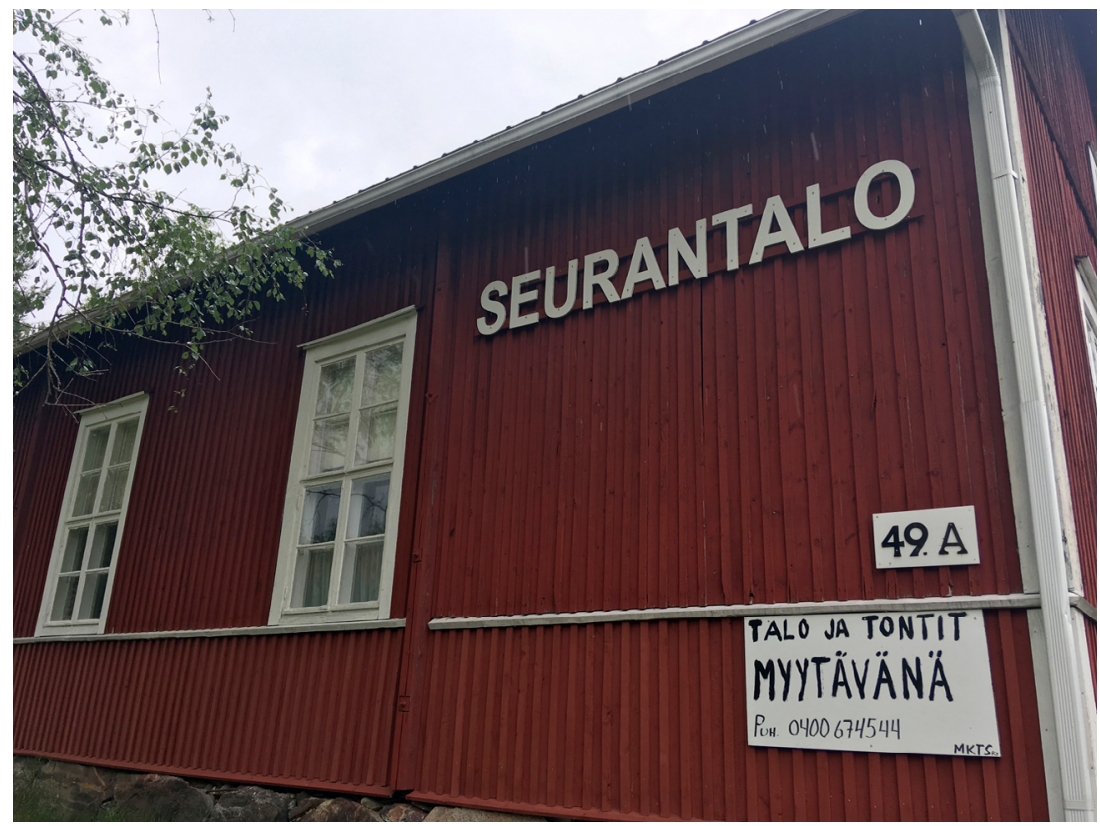

Kuva: Sanna Ryynänen / Varistaipaleen seurantalo, Heinävesi

\section{Kohtaamisia}

Perjantai 5.7.2019 - Salin suljetulle ovelle alkaa jo muodostua hyttyslauman ympäröimä ruuhka. Sitten ovi aukeaa, ja leveää Savon murretta puhuva näytelmän hahmo Klaus (Jonnakaisa Risto) alkaa toivottaa yleisöä letkeästi höpötellen tervetulleeksi "hyvinvointitapahtummaan". Myös näytelmän muut henkilöt, hermostuneen hössöttävä Kerttu (Janna Räsänen), tehokkaan kireä Hannaleena (Pietu Wikström) ja sliipattu Oliver (Boodi Kabbani) jalkautuvat istumapaikkoja etsiskelevän yleisön joukkoon, jutellen roolihahmoinaan ihmisten kanssa ja kommentoiden toisilleen salin täyttymistä. Muistelen eilen lukemaani yleisöpalautetta, jossa kiitettiin lämmintä 
tunnelmaa, jonka näyttelijöiden yleisöön ottama kontakti saa aikaan: "jää semmonen kiva filis, et me katsojat ei olla pelkkiä maksavia uhreja jotka tulee sinne vaan että meidät otetaan niinku vastaan, et ollaan tervetulleita”.

Saimaan Teatterin toimintatavalle on vuosien kuluessa muodostunut tunnusomaiseksi se, että teatteriesitys ei tapahdu ainoastaan näyttämöllä esitykselle varatun aikarajan puitteissa, vaan näyttelijät tulevat rooleissaan yleisön joukkoon jo ennen näytelmän alkua. Saimaan Demokraattinen Tasavalta -näytelmässä itsessään oli myös kevyitä yleisöä osallistavia elementtejä, esimerkiksi yhteislaulua, ja esitys päättyi yhden kappaleen mittaisiin lavatansseihin sekä mahdollisuuteen jäädä keskustelemaan esityksen teemoista. Näytelmä noudatteli tyylilajiltaan Saimaan Teatterin omaksumaa ja esityksissään edelleen kehittelemää "nykykansanteatteria", joka toisaalta jatkaa kesäteatteriperinnettä ja on sellaisenaan tuttua ja toisaalta horjuttaa kesäteatterin konventioita esittämisen tavoilla, juoninäytelmistä poikkeavilla muodoilla ja aihevalinnoilla sekä pyrkimällä yhdistämään katsojien kohtaaminen osaksi esityksiä.

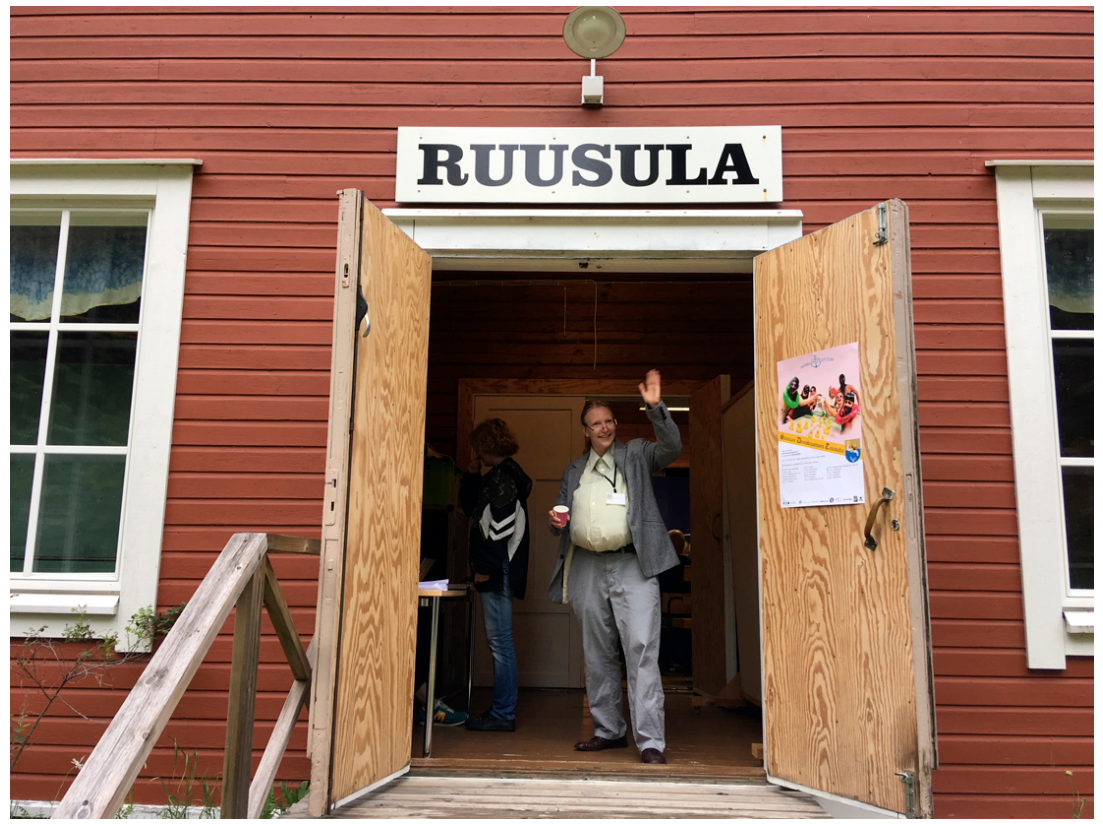

Kuva: Sanna Ryynänen / Klaus (Jonnakaisa Risto) 
Saimaan Teatterin näytelmille on myös tyypillistä yhteiskunnallisten teemojen kutominen osaksi esitystä. Kesän 2019 näytelmä oli saanut alkuinnoituksensa Heinävedelle suunnitellusta kaivoshankkeesta, joka ryöpsähti laajempaan tietoisuuteen juuri siinä vaiheessa, kun työryhmä loppukesällä 2018 alkoi pohtia seuraavan kesän näytelmän aihetta ja laatia rahoitushakemuksia. Näytelmä rakentui hyvinvointitapahtumaksi, jonka kaksi Heinäveden kunnanvaltuuston kuvitteellista jäsentä, keski-ikäinen, mitä ilmeisimmin kaivoshanketta kannattava, suulaasti höpöttelevä Klaus (Jonnakaisa Risto) ja nuori, ensimmäistä kauttaan kunnanvaltuustossa istuva, vihreitä arvoja kannattava ja kaivoshanketta vastustava Hannaleena (Pietu Wikström) olivat saaneet tehtäväkseen järjestää Saimaan alueen kunnissa. Järjestelyjoukoissa hääräsivät myös Hannaleenan äiti, kunnankanslian sihteeri Kerttu (Janna Räsänen) sekä Hannaleenan Pariisin ilmastokokouksesta löytämä poikaystävä Oliver (Boodi Kabbani), joka työskenteli kunnankansliassa harjoittelijana ja haikaili yhteisen ajan perään Hannaleenan kanssa. Klaus johdatti tervetulopuheenvuorossaan yleisön tilaisuuden henkeen: nyt ei puhuta ikävistä tai vaikeista asioista vaan pidetään hauskaa. Hannaleena yritti puolestaan tuoda tilaisuuteen myös asiasisältöä ja oli valinnut lähestymiskulmakseen luennoida ympäristövaikutusten arvioinnin menetelmästä ja sen sudenkuopista, "koska kuntalaisen hyvät vaikutusmahdollisuudet ovat olennainen osa heidän hyvinvointiaan". Esityksen teemat jatkuvat käsiohjelman kanssa jaettavassa tekstissä "Näkökulmia kaivosteollisuuteen ja kansalaisten vaikuttamismahdollisuuksiin" (Peltola \& Ryynänen 2019).

Kesän 2019 yleisöpalautteessa toistui kokemus siitä, että näytelmä oli herätellyt katsojiaan eri tavoin. Se herätti tajuamaan kaivoshankkeiden kiemuroita ja sai hakemaan tietoa Heinävedelle suunnitellusta kaivoshankkeesta. Se herätti pohtimaan demokratiaa ja demokratian tilaa sekä herätti huomaamaan ja ajattelemaan paikallisyhteisöön ja kunnalliseen päätöksentekoon liittyviä asioita, joita ei ole ennen tullut ajatelleeksi. Se herätti tunteita ja samastumisen kokemuksia. Näytelmän osallistavasta otteesta luettiin myös viesti näytelmän demokratiateemoihin liittyen: kukaan ei ole vain sivustakatsoja. "Mun mielestä se [alkujutustelu] oli ihan hauska, se viesti meille katsojillekin sitä, että me ihan oikeesti ollaan myös mukana näissä asioissa, sitä kautta, että ei olla vaan seuraajia, vaan nää asiat on meidän keskuudessa ja vaikuttaa meihin.” (Katsojahaastattelu, kesä 2019.)

Saimaan Teatterille erilaisten ihmisten kohtaamiset ja yhdessä rakentuvat kokemukset ovat keskeinen osa toimintaa myös teatteriesityksen 
ulkopuolella. Saimaan Teatteri ei toteudu vain seurantalojen lavoilla, vaan kesäkiertue on kuin yksi suuri tapahtuma yllättävinekin kohtaamisineen. Se tuo yhteen Saimaan alueen kesä- ja vakituiset asukkaat, mikkeliläisen Ekin Partion partiolaiset laivoineen, seurantaloja pyörittävien yhdistysten vastuuhenkilöt, paikalliset talkoolaiset kuljetustraktoreineen, peräkärryineen ja väliaikatarjoiluineen sekä tiiviin ja intiimin laivaelämän marinoiman teatterin työryhmän kavereineen. Esityksissä kohtaavat paitsi työryhmä ja yleisö myös paikalliset asukkaat ja kesäasukkaat, jotka eivät muuten välttämättä juurikaan kohtaisi toisiaan.

Torstai 11.7.2019 - Kahdenkymmenen minuutin väliaika alkaa vähän ennen kahdeksaa. Väliaikatarjoiluista vastaavat paikallisen kyläyhdistyksen naiset. Väliaikatarjoilut muistuttavat osaltaan siitä, miten paljon erilaista työtä kiertueteatterin yhteen esitykseen tiivistyy. Se ei ole vain teatteriryhmän työtä vaan myös paikallisten kuljetusapulaisten ja kahvilanpitäjien työtä sekä moninaista yhteydenpitoa vaativaa sopimista ja valmistelua sekä ennen kiertuetta että ennen jokaista esitystä. Esitykset eivät toteutuisi ilman näitä paikallisia kyläyhdistyksiä, nuorisoseuroja tai työväenyhdistyksiä. Tämä on yhteistyötä, josta vain pieni osa näkyy yleisölle.

\section{Kohti teatterin sosiaalipedagogiikkaa}

Keskustelu teatterin yhteiskunnallisuudesta, samoin kuin teatteritekojen kehystäminen yhteiskunnallisiksi tai poliittisiksi on kokenut jonkinlaisen uuden tulemisen 2000-luvulla. Puhutaan esimerkiksi teatterin sosiaalisesta käänteestä (Jackson 2011, 17) ja esityksen uudesta poliittisuudesta (Porkola 2014, 64-68). Aiheiden, sisältöjen ja teosmuodon lisäksi yhteiskunnallisiksi tai poliittisiksi teoiksi ymmärretään esimerkiksi teoksen ja katsojan/kokijan vuorovaikutus ja sen myötä muodostuvat suhteet sekä tekemisen tavat, työryhmäprosessit ja niihin liittyvät valtasuhteet (esim. Carroll, Jürs-Munby \& Giles 2013; Porkola 2014, 67-68). Teatterin yhteiskunnallisuuden pohtiminen on siis laventunut erityisesti taiteensosiologisille analyyseille ominaisista, teatterin yhteiskunnallista roolia ja paikkaa jäsentävistä teemoista myös kohti näkökulmia, jotka liittyvät vielä tiiviimmin juuri sosiaalipedagogiikan alaan kohtaamisia, suhteita ja dialogia korostaessaan.

Olen tässä tekstissä luonut esimerkinomaisia silmäyksiä Saimaan Teatteri -kiertuekokemusten kautta sellaisiin teatterin tekemisen ulottuvuuksiin, jotka ovat erityisen kiinnostavia alustavasti hahmottelemani teatterin 
sosiaalipedagogiikan näkökulmasta, eli tuonut esiin Saimaan Teatterin kiertuetoimintaa yhteisöllisenä tilana, pohtinut teatterin toimintatapaa esimerkkinä jalkautuvasta ja kulttuurisen demokratisaation periaatetta edustavasta teatterityöstä sekä kuvannut esimerkinomaisesti Saimaan Teatteria kohtaamisten mahdollistajana.

Halusin kirjoittaa kiertueteatterin elämästä jotain sellaista, mitä ei ehkä yleensä tulla aukikirjoittaneeksi: katkelmia kiertue-elämän arjesta näkökulmanani ennen kaikkea se valtava määrä omistautumista ja työtä, mitä kiertävän teatteriesityksen toteuttaminen vaatii. Tässä suhteessa tekstini on myös kunnianosoitus Saimaan Teatterille ja sen kesän 2019 työryhmälle, sekä kaikille teatteri- ja muille kiertäville ryhmille, jotka tekevät vastaavaa työtä.

Sosiaalipedagogiikan alalla keskustelu taiteesta yhteiskunnassa liittyy keskeisellä tavalla kulttuurisen demokratisaation ja kulttuurisen demokratian näkökulmiin (esim. Nivala \& Ryynänen 2019, 213-215). Saimaan Teatterin toiminnan näkökulmasta niistä keskeisempi kulttuurinen demokratisaatio tarkoittaa taiteen ja kulttuurin saavutettavuuden ja tavoittavuuden lisäämistä. Sen taustalla on ajatus siitä, että taiteen vaikutuspiiriin päätyminen on monin tavoin merkityksellistä. Taide voi tarjota arjesta irrottavia, upottavan nautinnollisia tai kriittisesti herätteleviä kokemuksia (esim. Mäki 2018, 49). Taide voi herkistää näkemään ja kokemaan uusilla tavoilla ja uudenlaisista näkökulmista. Se voi harjaannuttaa empatiataitojamme eli kykyämme asettua toisten ihmisten asemaan (esim. Nussbaum 2012; ks. myös Aaltola \& Keto 2018). Taide on merkityksellistä, koska se on pohjimmiltaan hyödytöntä. Kulttuurisen demokratisaation edistäminen on kannanotto siitä, että taidekokemusten ei tulisi jäädä vain tiettyjen ihmisten ja ihmisryhmien saavutettaviksi vaan niiden tulisi olla avoinna ja tavoitettavissa aivan kaikille.

Tällanen kiertävä teatteri, joka kiertää paikasta toiseen, se on älyttömän hyvä, se tuo sen teatterin paljon lähemmäs ihmisiä kuin nää paikallaan olevat teatterit. Eihän tässäkään [Taipalsaarelta] Lappeenrantaan oo ku sen viitisentoista kilometriä, pääsee katsomaan kesäteatteria, on tarjontaa useampaakin, mut kun se tulee tänne omaan kuntaan ni tavallaan tää meidän oman kunnan kesääki rikastuttaa kovasti. Se on paljo helpompi lähtee teatteriin, ku se tulee oman kunnan alueelle. [...] On hyvä, että on tämmönen kiertävä teatteri, siin on jotain sellasta vanhan ajan perinnettä mukana, sitähän on ollu joskus kaks, kolkytä- 
luvuilla näitä kiertäviä teattereita, ni se tavallaan herättää sitä vanhaa hommaa henkiin, se on hyvä asia, se on piristävää. (Yleisöhaastattelu, kesä 2019.)

Koneen Säätiö rahoitti tutkijan työni Saimaan Teatterin vuoden 2019 kesäkiertueella ja rahoittaa myös vuonna 2020 käynnistyvää, mm. Saimaan Teatterin toimintaan perehtyvää kolmivuotista tutkimushankettani "Lähiöbaareissa ja seurantaloilla. Tutkimus teatterista ja esittävistä taiteista yhteiskunnallisina tekoina”.

\section{LÄHTEET}

Aaltola, E. \& Keto, S. 2018. Empatia - myötäelämisen tiede. Helsinki: Into Kustannus.

Carroll, J., Jürs-Munby, K. \& Giles, S. 2013. Introduction: Postdramatic Theatre and the Political. Teoksessa K. Jürs-Munby, J. Carroll \& S. Giles (Eds.) Postdramatic Theatre and the Political. International Perspectives on Contemporary Perspective. London, New Delhi, New York, Sydney: Bloomsbury, 1-30.

HS 13.6.2013: "Huumetutkija: Diilerit syrjäyttivät ystävät". Saatavissa https://www.hs.fi/ elama/art-2000002645193.html (haettu 3.8.2019).

Jackson, S. 2011. Social works. Performing art, supporting publics. New York \& London: Routledge.

Kanavan Varrelta. Kesä 2019.

Mäki, T. 2018. Taiteen tehtävä. Helsinki: Into Kustannus.

Nivala, E. \& Ryynänen, S. 2019. Sosiaalipedagogiikka - kohti inhimillisempää yhteiskuntaa. Helsinki: Gaudeamus.

Nussbaum, M. 2012. Not for Profit. Why Democracy Needs the Humanities. Princeton:

Princeton University Press (ilm. alun perin 2010; suomeksi 2012, Talouskasvua tärkeämpää, suom. Timo Soukola, Helsinki: Gaudeamus.)

Peltola, P. \& Ryynänen, S. 2019. Näkökulmia kaivosteollisuuteen ja kansalaisten vaikutusmahdollisuuksiin. Saimaan Teatteri. Saatavissa http://saimaanteatteri. fi/?page_id=867 (haettu 5.8.2019).

Porkola, P. 2014. Esitys tutkimuksena - näkökulmia poliittiseen, dokumentaariseen ja henkilökohtaiseen esitystaiteessa. Väitöstutkimus. Taideyliopiston Teatterikorkeakoulu.

Yle 2006. Aikapommi oli reippaasti edellä aikaansa. 8.9.2006. Saatavissa https://yle. fi/aihe/artikkeli/2006/09/08/aikapommi-oli-reippaasti-edella-aikaansa (haettu 27.8.2019). 